while six were treated with sulphamethoxazole and trimethoprim and all six were cured. This observation is of interest because Str. faecalis is resistant to sulphamethoxazole but sensitive to trimethoprim.

Side-effects observed in the present series were few and trivial. One patient on sulphamethoxazole-trimethoprim $(10: 1)$ developed a pruritic rash on the limbs and trunk, which rapidly improved, and another patient on the same formulation developed pruritus without a rash. This patient was receiving a number of other drugs at the time, and the role of the sulphamethoxazole-trimethoprim in the production of the pruritus was very doubtful. The four patients out of 81 receiving trimethoprim-sulphamethoxazole who died during the course of this trial all died of causes unrelated to their treatment-two died of carcinomatosis, one with a cerebrovascular accident, and one with chronic renal failure. One patient on sulphamethoxazole alone died of bronchopneumonia.

The better formulation of sulphamethoxazole-trimethoprim appeared to be that containing the two drugs in the ratio $5: 1$, since this gave a cure rate of $92 \%$ compared with $84 \%$ for the $10: 1$ formulation. Because of the very low. failure rates with the two formulations of sulphamethoxazole-trimethoprim, formal tests of statistical significance for this difference are not applicable. The patients took two tablets twice a day for five days, and this appeared to be acceptable. The smaller amount of sulphamethoxazole in the $1: 5$ combination (Septrin) tablets than in the other two treatments was to ensure a suitable size of tablet so that the pattern of tablet taking in the three groups was acceptable to all patients.
In view of the very high cure rate in urinary infections in hospital inpatients combined with a low incidence of side-effects of a non-serious nature and an acceptable formulation, we consider that sulphamethoxazole-trimethoprim should be more widely used. There appears to be no reason why it should not also be used in domiciliary practice. We have no experience of the use of this combination in the treatment of urinary infections in children or in pregnant women and do not advocate its use in these infections until more is known of its sideeffects.

We are grateful to our clinical colleagues at the Whittington Hospital for permission to treat patients under their care and to the nursing staff and the technicians in the bacteriology laboratory for their enthusiastic help. Dr. A, F. Mohun, Dr. J. G. A. McSorley, and Dr. H. E. S. Pearson gave helpful advice and encouragement. Dr. A. S. E. Fowle, of the Wellcome Research Foundation, supplied the sulphonamide and trimethoprim used in the trial and provided valuable information and assistance throughout. Dr. S. R. M. Bushby of the Wellcome Foundation kindly performed the in-vitro studies on potentiation of sulphonamide by trimethoprim.

\section{REFERENCES}

Bushby, S. R. M., and Hitchings, G. H. (1968). Brit. F. Pharm., 33, 72. Darrell, J. H., Garrod, L. P., and Waterworth, P. M. (1968). F. clin. Path., 21, 202.

Grüneberg, R. N., and Brumfitt, W. (1967). Brit. med. F., 3, 649.

Roth, B., Falco, E. A., Hirchings, G. H., and Bushby, S. R. M. (1962). 7. med. pharm. Chem., 5, 1103.

Schneider, M., Schwarzenberg, L., Cattan, A., Schlumberger, J.-R., Amiel, J.-L., and Mathé, G. (1965). Presse méd., 73, 893.

\title{
Relationship of a Degenerative Tropical Neuropathy to Diet Report of a Field Survey
}

\author{
B. O. OSUNTOKUN,* M.B., B.S., M.R.C.P. ; G. L. MONEKOSSO, † M.D., F.R.C.P.ED., D.T.M.\&H. \\ J. WILSON‡ M.B., PH.D., M.R.C.P.
}

Brit. med. F., 1969, 1, 547-550

\begin{abstract}
Summary : A survey of neurological abnormalities in two Nigerian villages preselected for their differing consumption of cassava has shown that a degenerative neuropathy occurs with relatively high frequency in the village (Ososa) where cassava consumption was high.

It is suggested that eating cassava results in exposure to cyanide, as shown by a raised plasma thiocyanate level, and that the latter, together with other factors, may contribute to the pathogenesis of "tropical neuropathy."
\end{abstract}

\section{Introduction}

It has been suggested that chronic cyanide intoxication from dietary sources may be a contributory factor in the aetiology of a degenerative neurological disorder in Nigeria (Clark, 1935; Monekosso and Annan, 1964 ; Monekosso and Wilson, 1966 ; Osuntokun, 1968). The main features of the fully developed

* Physician in Neurology, University College Hospital, Ibadan, Nigeria. † Professor of Medicine, University of Lagos, Nigeria. Present address: W.H.O. Professor of Medicine and Dean of the Faculty of Medicine, University of East Africa, Dar-es-Salaam, Tanzania.

¥ Member of Scientific Staff, M.R.C. Clinical Genetics Research Unit, Institute of Child Health and Institute of Neurology, London W.C.1. "ataxic syndrome"-optic atrophy, nerve deafness, and sensory spinal ataxia - have been well documented (Money, 1958). Tropical amblyopia, probably a fragmentary form of the fully developed syndrome, was first studied in Nigeria by Moore (1930, 1932, 1934a, 1934b, 1937), who associated it with poor diet and thought that a nutritional deficiency of riboflavine and/or a dietary toxin should be implicated.

The association of angular stomatitis, glossitis, and scrotal dermatitis with tropical amblyopia has been confirmed by observers in different countries in peacetime and during the second world war (Denny-Brown, 1947 ; Smith and Woodruff, 1950 ; Cruickshank, 1952 ; Monekosso, 1963 ; Monekosso and Ashby, 1963) ; these mucocutaneous deficiency lesions have also been recognized in association with the fully developed ataxic syndrome (Scott, 1918 ; Landor and Pallister, 1935; DennyBrown, 1947 ; Knüttgen, 1955 ; Money, 1958 ; Ebrahim and Haddock, 1964 ; Monekosso and Annan, 1964). Many observers have therefore sought a link between vitamin-B-complex deficiency (especially of riboflavine) and the ataxic neurological syndrome. Although in a number of respects the condition resembles clinically subacute combined degeneration as seen in European communities, serum vitamin $B_{12}$ levels are not reduced. Moreover, clinical "ariboflavinosis" is very common 
in some tropical communities, but neuropathy is much less frequent, and disorders associated with severe deficiency of the vitamin B complex-for example, tropical sprue-are not of ten associated with gross neuropathy.

The frequency of both mucocutaneous and neurological disturbances in cassava-eating peoples of Nigeria led Clark (1935) to postulate that visual failure in tropical amblyopia might be due to intoxication by cyanide in cassava, which forms a major part of Nigerian diet.

There are several varieties of cassava, but all contain a cyanogenetic glycoside (linamarin) and a hydrolase (linase) which rapidly liberate relatively large quantities of cyanide when the leaves, stem, or farinaceous roots are traumatized. The bitter variety of cassava (Manioc utilissima), which is most used in Nigeria, has particularly large concentrations of cyanogenetic material in the outer integument of the tuberous root, from which free cyanide penetrates inwards and may thus contaminate the edible part.

In this study we present a more detailed correlation of clinical, dietary, and metabolic data to try to define more clearly an association between cassava consumption and the occurrence of neurological disease. The prevalence of "tropical neuropathy" has been estimated in the adult population of two villages where cassava forms widely differing proportions of the daily nourishment, and the data have been compared with serum thiocyanate and vitamin $B_{12}$ concentrations.

\section{Plan of the Survey}

The villages of Ososa and Akinmorin were selected solely because they were conveniently sized and situated villages not far from Lagos and Ibadan, in districts of high and low cassava consumption respectively. They were not selected from any foreknowledge of the frequency of neurological diseases there.

A census of the population over 10 years of age resident during the months of February and March 1967 was conducted and dietary habits were confirmed in a pilot survey of the randomly selected population, $95 \%$ of whom responded to requests for further co-operation for blood sampling.

Once it had been established from this pilot study that the diet of the two populations differed principally in respect of the proportion of cassava, a general invitation was offered through the "town crier" for anyone suspecting that he was ailing to allow himself to be examined. A more rigidly designed sampling method was unacceptable in these rural villages because of the inevitable shy uncertainty, even hostile suspicion, which greets intrusion by strangers.

It was quickly realized that the occurrence of an ataxic syndrome was well recognized in the indigenous population of Ososa, where it is known as " rase-rase" or "lagero," but not at Akinmorin. This in itself was a highly significant observation, and allowed a more specific request for collaboration than the general invitation possible at Akinmorin.

All the subjects thus self-selected were examined clinically and blood samples obtained for laboratory examination.

\section{Laboratory Methods}

Plasma thiocyanate was determined by the method of Aldridge (1945) in deproteinized plasma (Wilson, 1965). Serum vitamin $\mathrm{B}_{12}$ was determined microbiologically with Lactobacillus leichmannii, duplicate determinations being performed on aliquots of serum which had been separately deproteinized with and without the addition of cyanide in the extracting buffer (Matthews, 1962).

\section{Results}

In a pilot survey at Ososa and Akinmorin it was confirmed that the two communities were similar in respect of mean age, weight, and height, and in the prevalence of sickling. The average numbers of children per woman of child-bearing age were 4.5 and 5.0 at Ososa and Akinmorin respectively. There was a marked difference in the amount of cassava eaten $(64.3 \%$ cassava meals at Ososa, and $10.8 \%$ at Akinmorin), and this was reflected in the difference in plasma thiocyanate and serum vitamin $B_{12}$ concentrations which are shown in Table I. In Ososa cassava formed the staple diet, but in Akinmorin it was eaten much less frequently, and when eaten was usually mixed with two parts of yam flour.

TABLE I.-Mean Serum Thiocyanate and Vitamin $B_{12}$ Concentrations in Randomly Selected Samples from Subjects in Pilot Survey

\begin{tabular}{|c|c|c|}
\hline & Ososa & Akinmorin \\
\hline $\begin{array}{l}\text { Mean plasma thiocyanate }(\mu \mathrm{M} / 100 \mathrm{ml} \text { ) } \\
\text { Difference significant st }\end{array}$ & $\begin{array}{l}\quad 6 \cdot 7(n=30) \\
\text { S.E. M. } \pm 0 \cdot 8 \\
\text { stically } 0.05>P\end{array}$ & $\begin{array}{l}4 \cdot 6(n=43) \\
\text { S.E.M. } \pm 0 \cdot 2\end{array}$ \\
\hline $\begin{array}{l}\text { Mean serum vitamin } \mathbf{B}_{12} \text { : } \\
\text { Total with cyanide extraction (A) } \\
\text { Total without cyanide extraction }(\mathbf{B}) \\
\text { B/A }(\%)\end{array}$ & $\begin{array}{l}492(n=16) \\
311 \\
63 \cdot 2(n=16) \\
\text { S.E.M. } \pm 3 \cdot 5\end{array}$ & $\begin{array}{l}597(n=24) \\
278 \\
46 \cdot 5(n=24) \\
\text { S.E.M. } \pm 4 \cdot 5\end{array}$ \\
\hline
\end{tabular}

In this and in subsequent tables Student's $t$ test of statistical significance is applied to the comparison of mean values.

Social and dietary data from the main survey at Ososa (high cassava) and Akinmorin (low cassava) are presented in Table II.

TABLE II.-Social and Dietary Data from Ososa and Akinmorin

\begin{tabular}{|c|c|c|c|c|}
\hline & & & Ososa & Akinmorin \\
\hline $\begin{array}{l}\text { Ascertained } \\
10 \text { years, ro } \\
\text { est } 25 \\
\text { Number exar } \\
\text { Males } \\
\text { Females }\end{array}$ & $\begin{array}{l}\text { popula } \\
\text { punded } \\
\text { mined } \\
\ldots \\
\ldots\end{array}$ & $\begin{array}{cc}\text { tion over } \\
\text { off to near- } \\
\ldots & \cdots \\
\cdots & \cdots \\
\cdots & \cdots \\
\cdots & \cdots\end{array}$ & $\begin{array}{r}2,275 \\
234 \\
112 \\
122\end{array}$ & $\begin{array}{r}1,500 \\
150 \\
63 \\
87\end{array}$ \\
\hline $\begin{array}{l}\text { Diet: } \\
\text { Cassava }\end{array}$ & \multicolumn{2}{|c|}{$\begin{array}{l}\text { Once daily } \\
\text { Twice daily } \\
\text { Thrice daily }\end{array}$} & $\begin{array}{r}25 \\
51 \\
140\end{array}$ & $\begin{array}{r}80 \\
8 \\
0\end{array}$ \\
\hline $\begin{array}{c}\text { Social habits } \\
\text { Smoking } \\
\text { Alcohol } \\
\text { Colanuts }\end{array}$ & $\begin{array}{l} \\
\cdots \\
\cdots\end{array}$ & $\begin{array}{l}\cdots \\
\cdots\end{array}$ & $\begin{array}{l}44(18 \cdot 8 \%) \\
81(34 \cdot 6 \%) \\
64(27 \cdot 3 \%)\end{array}$ & $\begin{array}{l}25(16 \cdot 7 \%) \\
28(18 \cdot 7 \%) \\
72(48 \cdot 0 \%)\end{array}$ \\
\hline
\end{tabular}

The prevalence of mucocutaneous and other abnormalities usually believed to signify nutritional status are shown in Table III.

TABLE III.-Prevalence of Mucocutaneous Abnormalities in Subjects Examined

\begin{tabular}{|c|c|c|c|}
\hline & & Ososa & Akinmorin \\
\hline $\begin{array}{l}\text { Stomatoglossitis } \\
\text { Follicular hyperkeratosis } \\
\text { Corneal vascularization } \\
\text { Dental caries }\end{array}$ & \begin{tabular}{l|l}
$\ldots$ & \\
$\cdots$ & \\
$\cdots$ &
\end{tabular} & $\begin{array}{r}101(43 \cdot 1 \%) \\
55(23 \cdot 5 \%) \\
11(4 \cdot 7 \% \%) \\
121(51 \cdot 7 \%)\end{array}$ & $\begin{array}{c}9(6 \cdot 0 \%) \\
37(24 \cdot 7 \%) \\
1(0 \cdot 7 \%) \\
6(4 \cdot 0 \%)\end{array}$ \\
\hline
\end{tabular}

The frequencies of neurological symptoms and signs are shown in Table IV. It is clear from this that differences in the neurological status of the patients at Akinmorin and Ososa are quantitative not qualitative, but nevertheless, basing a diagnosis of the fully developed syndrome of tropical neuropathy on the coexistence of two or more of the following signs-optic atrophy, nerve deafness, sensory ataxia, and pyramidal abnormalities-the condition was diagnosed in 53 subjects $(22.6 \%$ of those surveyed) at Ososa and in $1(0.7 \%$ of those surveyed) at Akinmorin. It is of interest that the patient who was diagnosed at Akinmorin had developed the condition several years earlier when she had lived near Lagos, where cassava consumption was much higher than at Akinmorin. Since moving there her neurological troubles had not apparently progressed. 
TABlE IV.-Prevalence of Neurological Symptoms and Signs in Subjects Examined at Ososa and Akinmorin

\begin{tabular}{|c|c|c|c|c|c|}
\hline & & & & Ososa & Akinmorin \\
\hline $\begin{array}{l}\text { Symptoms: } \\
\text { Visual difficulty } \\
\text { Tinnitus } \\
\text { Hard of hearing } \\
\text { Heaviness of legs } \\
\text { Paraesthesiae } \\
\text { Unable to feel the } g\end{array}$ & $\begin{array}{l}\ldots \\
\therefore \\
\therefore \\
\therefore \\
\text { round }\end{array}$ & $\begin{array}{l}\cdots \\
\cdots \\
\cdots \\
\cdots\end{array}$ & $\begin{array}{l}\cdots \\
\cdots \\
\cdots \\
\cdots\end{array}$ & $\begin{array}{c}104(44 \cdot 4 \%) \\
36(15 \cdot 4 \%) \\
17(7 \cdot 3 \%) \\
53(22 \cdot 6 \%) \\
69(29 \cdot 5 \%) \\
71(30 \cdot 3 \%)\end{array}$ & $\begin{array}{c}26(17 \cdot 3 \%) \\
4(2 \cdot 7 \%) \\
2(1 \cdot 3 \%) \\
2(1 \cdot 3 \%) \\
6(4 \cdot 0 \%) \\
3(2 \cdot 0 \%)\end{array}$ \\
\hline $\begin{array}{l}\text { Signs: } \\
\text { Visual acuity <6/6 } \\
\text { With cataracts } \\
\text { Without cataracts } \\
\text { Optic disc pallor } \\
\text { Choroidoretinitis } \\
\text { Hypertensive retino } \\
\text { Impaired hearing } \\
\text { Conductive deafnes }\end{array}$ & $\begin{array}{l}\cdots \\
\cdots \\
\cdots \\
\text { pathy } \\
\cdots\end{array}$ & $\begin{array}{l}\cdots \\
\cdots \\
\cdots \\
\cdots \\
\cdots\end{array}$ & $\begin{array}{l}\because \\
\therefore \\
\cdots \\
\cdots \\
\cdots \\
\cdots\end{array}$ & $\begin{array}{l}11 \\
3 \\
8(3 \cdot 4 \%) \\
53(22 \cdot 6 \%) \\
11(4 \cdot 7 \%) \\
11(4 \cdot 7 \%) \\
34(14 \cdot 5 \%) \\
0\end{array}$ & $\begin{array}{l}3 \\
3 \\
0(0 \%) \\
0(0 \%) \\
0 \\
1 \\
3(2 \%) \\
1\end{array}$ \\
\hline $\begin{array}{l}\text { Gait: } \\
\text { Ataxia . . } \\
\text { Inability to walk toe } \\
\text { Romberg sign positi }\end{array}$ & to heel & $\cdots$ & $\begin{array}{l}\ldots \\
\cdots\end{array}$ & $\underset{2}{9}(10 \cdot 0 \%)$ & $\begin{array}{l}1 \\
1\end{array}(0 \cdot 7 \%)$ \\
\hline 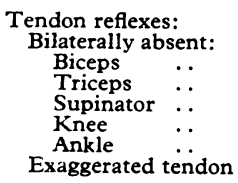 & $\begin{array}{l}\ldots \\
\because \\
\because \\
\text { reflexes }\end{array}$ & $\begin{array}{l}\because \\
\therefore \\
\therefore\end{array}$ & $\begin{array}{l}\because \\
\because \\
\because \\
\therefore\end{array}$ & $\begin{array}{l}0 \\
13(5 \cdot 5 \%) \\
15(6 \cdot 4 \%) \\
40(17 \cdot 0 \%) \\
52(22 \cdot 2 \%) \\
19(8 \cdot 1 \%)\end{array}$ & $\begin{array}{l}0 \\
2(1 \cdot 3 \%) \\
1(0 \cdot 7 \%) \\
8(5 \cdot 3 \%) \\
18(12 \%) \\
2(1 \cdot 3 \%)\end{array}$ \\
\hline $\begin{array}{l}\text { Plantar reflexes: } \\
\text { Absent bilaterally } \\
\text { Bilateral extensor } \\
\text { Unilateral extenso } \\
\text { Equivocal ... }\end{array}$ & $\ldots$ & $\begin{array}{l}\cdots \\
\cdots \\
\cdots\end{array}$ & $\begin{array}{l}\cdots \\
\therefore \\
\therefore\end{array}$ & $\begin{array}{l}56(23.9 \%) \\
14(5 \cdot 9 \%) \\
3 \\
0\end{array}$ & $\begin{array}{l}4(2 \cdot 7 \%) \\
0(0 \%) \\
0 \\
1\end{array}$ \\
\hline $\begin{array}{l}\text { Sensory signs: } \\
\text { Impaired vibration } \\
\text { Impaired joint-posit } \\
\text { Impaired two-point } \\
\text { Calf tenderness }\end{array}$ & $\begin{array}{l}\text { ion } \\
\text { discrimi } \\
\ldots\end{array}$ & $\begin{array}{l}\ldots \\
\ddot{a n a t i o n} \\
\ldots\end{array}$ & $\cdots$ & 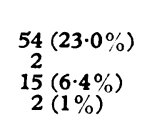 & $\begin{array}{r}10(6 \cdot 7 \%) \\
1(0.7 \%) \\
1(2 \cdot 0 \%)\end{array}$ \\
\hline
\end{tabular}

As was to be expected, the survey disclosed other probably unrelated conditions (Table V). Although this morbidity was generally more common at Ososa, the differences are probably not of significance.

TABLE V.-Other Clinical Conditions Detected

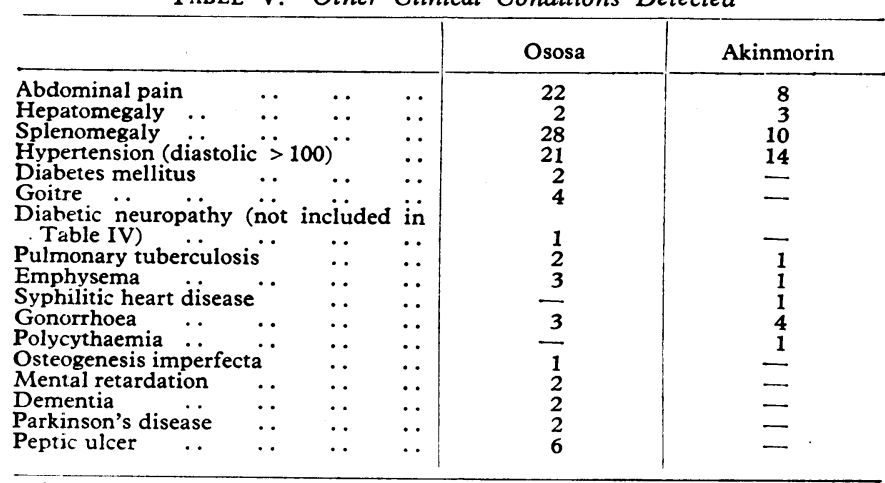

The mean plasma thiocyanate concentrations in various groups of subjects examined in the two villages are compared in Table VI, subdivided according to smoking habits.

The numbers of smokers are too few and the amount of tobacco consumed too small to allow statistically valid conclusions to be drawn about most of the groups. Moreover, there was no significant difference in the proportions of smokers in the various categories ( 8 out of 30 smokers had the disease, 30 out of 103 non-smokers at Ososa), suggesting that smoking did not contribute substantially to the overall clinical changes seen, though smoking did affect thiocyanate levels.

In Table VII the mean thiocyanate concentrations in the population examined at Ososa are presented according to occupation and neurological status.

If, among the total of 60 normal subjects at Ososa, the proportion of cassava farmers and processers ( 23 out of 60 ) is truly representative of the proportion of the total population of the village thus employed, the excessive frequency of this occupa- tion among patients found to be suffering from tropical ataxia (20 out of 37 ) suggests that there may be an occupational hazard, but this difference is not statistically significant with the numbers available $\left(\chi^{2}=2 \cdot 3\right.$, D.F. $\left.1,0.2>P>0.1\right)$.

TABLE VI.-Mean Plasma Thiocyanate Concentrations in Smokers (S.) and Non-smokers (N.S.) at Akinmorin and Ososa. At Akinmorin Subjects are Also Subdivided According to Cassava Intake

\begin{tabular}{|c|c|c|c|}
\hline & \multicolumn{2}{|c|}{$\begin{array}{l}\text { Mean Plasma Thiocyanate } \\
\text { Concentration ( } \mu \text { mole/ } \\
100 \text { ml.) with S.E.M. }\end{array}$} & \multirow{2}{*}{$\begin{array}{c}\text { Mean } \\
\text { Age in } \\
\text { Years } \\
\text { with } \\
\text { Range }\end{array}$} \\
\hline & N.S. & s. & \\
\hline $\begin{array}{l}\text { Akinmorin } \\
\text { 1. "Low" cassava (none or }<3 \\
\text { 2. "Meals/week) } \\
\text { 3. " Migh" cassava (> once daily) } \\
\text { 4. All Akinmorin subjects combined }\end{array}$ & $\begin{array}{l}2 \cdot 4 \pm 0 \cdot 2 \\
n=28 \\
5 \cdot 3 \pm 0 \cdot 7 \\
n=42 \\
5 \cdot 8 \pm 1 \cdot 6 \\
n=10 \\
4 \cdot 4 \pm 0 \cdot 3 \\
n=80\end{array}$ & $\begin{array}{l}9 \cdot 3 \pm 2 \cdot 6 \\
n=7 \\
9 \cdot 8 \pm 1 \cdot 6 \\
n=11 \\
12 \cdot 6 \\
n=2 \\
9 \cdot 9 \pm 1 \cdot 4 \\
n=20\end{array}$ & $\begin{array}{c}43 \cdot 9 \\
(13-70)\end{array}$ \\
\hline $\begin{array}{l}\text { Ososa } \\
\text { 5. Patients with tropical neuropathy } \\
\text { 6. Patients with symptoms but with } \\
\text { insufficient signs of tropical } \\
\text { neuropathy } \\
\text { 7. Subjects without neurological } \\
\text { abnormality }\end{array}$ & $\begin{array}{c}9.3 \pm 0.9 \\
n=30 \\
7 \cdot 0 \pm 0.5 \\
n=15 \\
6.4 \pm 0.5 \\
n=58\end{array}$ & $\begin{array}{c}11 \cdot 6 \pm 2 \cdot 2 \\
n=8 \\
9 \cdot 6 \pm 1 \cdot 9 \\
n=3 \\
10 \cdot 0 \pm 1 \cdot 4 \\
n=19\end{array}$ & $\begin{array}{c}54 \cdot 2 \\
(31-72) \\
44 \\
(32-56) \\
44 \cdot 6 \\
(11-77)\end{array}$ \\
\hline
\end{tabular}

The following differences between mean plasma thiocyanate concentrations are statistically significant:

Smokers v. non-smokers, group $1(P<0.001)$.
Smokers v. non-smokers, group $2(P<0.001)$.

Group 1 v. group 2, non-smokers $(P<0.01>0.001)$.

Group 5 v. group 6, non-smokers $(\mathbf{P}<0.05>0.01)$.

Group 5 v. group 6, non-smokers $(P<0.05>0.01)$.

Smokers v. non-smokers, group $7(P<0.01>0.001)$.

Group 4 v. group 5, non-smokers $(P<0.05>0.01)$.

TABLE VII.-Mean Thiocyanate Concentrations ( $\mu$ mole $/ 100 \mathrm{ml}$.) With S.E.M. at Ososa, According to Occupation and Neurological Status

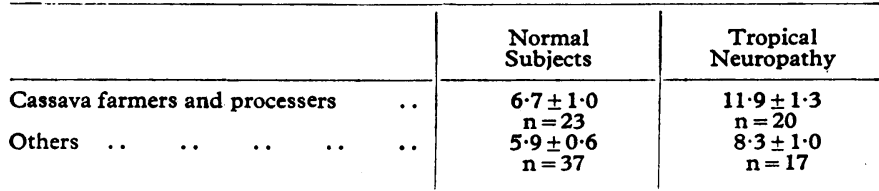

There is a statistically significant difference between levels in normal and affected cassava farmers and processers $(0.01>P>0.001)$, and between normal and affected subiects in other occupations $(0.05>\mathbf{P}>0.01)$. Comparing patients, there is also a statistically significant difference in mean thiocyanate levels between the farmers and

\section{Discussion}

One of the major difficulties in evaluating the role of possible environmental factors in the aetiopathogenesis of chronic neurological disease is that of relating "cross-sectional " clinical and laboratory data obtained over a very short period to a malady which has a relatively low incidence but a very chronic course. An essential prerequisite is that the condition being investigated has a measurable incidence, and, though no systematic estimate of incidence is possible here, it is known that new cases of the disease are still occurring in the district around Ososa. Another prerequisite is that the condition shall, so far as is possible, be studied in the environment where it occurs, despite the attendant disadvantages of field study in adverse terrain among a variously motivated, but on the whole suspicious, population. Hearsay evidence suggests that there has been no substantial change in dietary habits or in way of life during the past two decades in the two areas studied here, and it is therefore reasonable to try to relate contemporary nutritional and metabolic data to the occurrence of this disease.

Present clinical and laboratory evidence supports and amplifies earlier studies and observations (Clark, 1935 ; Monekosso and Wilson, 1966 ; Osuntokun, 1968), and shows an association between the occurrence of tropical neuropathy and the consumption of cassava. Data on thiocyanate concentrations are used inferentially in support of the suggestion that eating cassava results in exposure to cyanide, which is detoxicated to thiocyanate. Comparison of serum vitamin $\mathrm{B}_{12}$ " $\mathrm{CN}$-extract- 
ability" in subjects in the pilot study of the two villages is also consistent with this suggestion (Wilson and Matthews, 1966). There may also be an occupational hazard for those engaged in the growing and handling of cassava, though our numbers are too few to advance statistical support for this argument.

That such statistically valid correlations may be biologically coincidental is recognized, and it could be argued that cassava consumption is only indirectly involved, in so far as such heavy dependence on nearly pure carbohydrate could induce nutritional imbalances, particularly of protein, which are of more or less direct aetiopathological significance.

It is interesting to note, however, that differences between Ososa and Akinmorin are relative and not absolute. Not only are there varying amounts of cassava eaten, reflected in varying thiocyanate levels, but this relatively simple clinical survey has also revealed neurological abnormalities among the population at Akinmorin, similar to those at Ososa, though none is of sufficient severity as to constitute a clinically identifiable syndrome, except in one case in the special circumstances described above.

As emphasized elsewhere (Moore, 1930, 1932, 1934a, 1934b, 1937 ; Monekosso and Wilson, 1966 ; Osuntokun, 1968) cassava and cyanogen exposure may be one of several factors. Others could be riboflavine deficiency and abnormalities of vitamin $B_{12}$ metabolism, as well as infections. There may, however, be a conditioned abnormality of cyanide metabolism arising from the low protein intake and consequent lack of substrate (sulphurcontaining amino-acids) for cyanide detoxication (Osuntokun, Durowoju, McFarlane, and Wilson, 1968).

Although there are similarities between this disease and those seen in other tropical and subtropical areas-namely, prisoners of war, and in the West Indies-we féel that it would be unwise at present to assume that these represent clinical variants of the same disease, but obviously it is worth exploring the existence of abnormalities of cyanide metabolism in clinically similar conditions elsewhere.
A therapeutic trial of hydroxocobalamin (as a cyanide antagonist), riboflavine, and cysteine is now in progress.

We wish to thank our colleagues from the Wellcome Trust's working party on tropical neuropathies, the members of which were R. H. S. Thompson (chairman), W. R. S. Doll, M. J. S. Langman, D. M. Matthews, D. L. Mollin, R. D. Montgomery, W. R. Stanton, and P. O. Williams, for their help with this project, which was supported by a grant from the Trust.

\section{REFERENCES}

Aldridge, W. N. (1945). Analyst (Lond.), 70, 474.

Clark, A. (1935). W. Afr. med. F., 8, No. 4, p. 7.

Cruickshank, E. K. (1952). Vitam, and Horm., 10, 2.

Denny-Brown, D. (1947). Medicine (Baltimore), 26, 41.

Ebrahim, G. J., and Haddock, D. R. W. (1964). Trans, roy. Soc. trop. Med. Hyg., 58, 246.

Knüttgen, H. (1955). Z. Tropenmed. Parasit., 6, 472.

Landor, J. V., and Pallister, R. A. (1935). Trans. roy. Soc. trop. Med. Hyg., 29, 121.

Matthews, D. M. (1962). Clin. Sci., 22, 101.

Monekosso, G. L. (1963). f. trop. Med. Hyg., 66, 255. Monekosso, G. L., and Annan, W. G. (1964). Trop. geogr. Med., 16,
316.

Monekosso, G. L., and Ashby, P. H. (1963). W. Afr. med. F., 12, 226.

Monekosso, G. L., and Wilson, J. (1966). Lancet, 1, 1062.

Money, G. L. (1958). W. Afr. med. F., 7, 58.

Moore, D. G. F. (1930). W. Afr. med. ₹., 4, 46.

Moore, D. G. F. (1932). W. Afr. med. f., 6, 28.

Moore, D. G. F. (1934a). Ann. trop. Med. Parasit., 28, 295.

Moore, D. G. F. (1934b). W. Afr. med. F., 7, 119.

Moore, D. G. F. (1937). W. Afr. med. f., 9, 35.

Osuntokun, B. O. (1968). Brain, 91, 215.

Osuntokun, B. O., Durowoju, J. E., McFarlane, H., and Wilson, J. (1968). Brit. med. F., 3, 647.

Scott, H. H. (1918). Ann. trop. Med. Parasit., 12, 109.

Smith, D. A., and Woodruff, M. F. A. (1951) Spec. Rep. Ser. med. Res. Coun. (Lond.), No. 274.

Wilson, J. (1965). Clin. Sci., 29, 505.

Wilson, J., and Matthews, D. M. (1966). Clin. Sci., 31, 1.

\title{
Renal Damage after Acute Pyelonephritis
}

\author{
R. R. BAILEY,* M.B., M.R.A.C.P. ; P. J. LITTLE, $\dagger$ M.B., M.R.C.P. ; G. L. ROLLESTON, $\ddagger$ M.B., D.M.R.D., F.C.R.A.
}

Brit. med. F., 1969, 1, 550-551

\begin{abstract}
Ummary : Intravenous pyelograms done before, during, and after an attack of acute pyelonephritis in a 41year-old woman showed an increase in the size of both kidneys during the attack. The right kidney did not excrete the contrast medium during the acute episode. When function returned it became smaller, and three months after the attack of pyelonephritis this kidney was $1 \mathrm{~cm}$. shorter than before it.
\end{abstract}

\section{Introduction}

It has been difficult to show that acute renal infection in the adult causes any permanent renal damage. It is believed that in the case described here such damage has been demonstrated.

* Senior Medical Registrar, Christchurch Hospital, Christchurch, New Zealand.

t Renal Physician, Christchurch Hospital, Christchurch, New Zealand.

$\ddagger$ Director of Radiology, Christchurch Hospital, Christchurch, New Zealand.

\section{Case Report}

A 41-year-old spinster was admitted to hospital on 13 June 1968. In January 1968 an intravenous pyelogram was normal (Fig. 1). This investigation was carried out because of suspected haematuria. The finding of haematuria was not confirmed. Three urine cultures were sterile. Eight days before admission a dilatation and curettage was carried out because of menorrhagia. The bladder was catheterized previous to this procedure.

Forty-eight hours after curettage she developed intense terminal dysuria and frequency and noted her urine to be smelly and frothy. She had bilateral loin pain, fever, rigors, headache, and vomiting. A midstream urine culture grew over 100,000 coliform bacilli per ml. Ampicillin $250 \mathrm{mg}$. six-hourly was given.

On admission a diagnosis of acute pyelonephritis was made. Oral temperature was $38 \cdot 2^{\circ} \mathrm{C}$. and blood pressure $100 / 60 \mathrm{~mm}$. Hg. A midstream urine obtained on the day of admission had 6-10 leucocytes and over 50 red cells per high-power field and grew 3,000 klebsiella per ml. Blood culture grew klebsiella sensitive to kanamycin, cephaloridine, and tetracycline and resistant to ampicillin and sulphonamides. 